\title{
NEW DATA ON LICHENICOLOUS FUNGI OF THE TETERIV RIVER BASIN (UKRAINE)
}

\author{
N. V. Kapets and S. Y. KondratyuK \\ M. H. Kholodny Institute of Botany, 2 Tereshchenkivska Str., Kyiv, 01004 Ukraine \\ E-mails:kapets_n@ukr.net, ksya_net@ukr.net
}

(Received 6 July, 2018; Accepted 16 November, 2018)

\begin{abstract}
The data on 31 species of lichenicolous fungi (Abrothallus caerulescens, Arthonia phaeophysciae, Athelia arachnoidea, Cercidospora macrospora, Clypeococcum hypocenomycis, Cornutispora lichenicola, Erythricium aurantiacum, Heterocephalacria physciacearum, Intralichen christiansenii, Lichenochora obscuroides, Lichenoconium erodens, L. lecanorae, L. usneae, Lichenodiplis lecanorae, Lichenostigma cosmopolites, Lichenothelia convexa, L. scopularia, Marchandiomyces corallinus, Monodictys epilepraria, Muellerella pygmaea, M. erratica, Pronectria leptaleae, Pyrenochaeta xanthoriae, Sclerococcum sphaerale, Sphaerellothecium propinquellum, Stigmidium fuscatae, S. squamariae, S. xanthoparmeliarum, Taeniolella phaeophysciae, T. punctata, Xanthoriicola physciae) new to the Teteriv River Basin are provided. Further five species (Cercidospora crozalsiana, Lichenostigma epipolina, Lichenothelia tenuissima, Polysporina subfuscescens and Taeniolella beschiana) are new to Ukraine. Additional localities for all newly reported species are listed.
\end{abstract}

Key words: Cercidospora crozalsiana, lichenicolous fungi, Lichenostigma epipolina, Lichenothelia tenuissima, Polysporina subfuscescens, Taeniolella beschiana, Teteriv River Basin, Ukraine

\section{INTRODUCTION}

Lichenicolous fungi represent the special object of present study and about 200 taxa are known from Ukraine (Darmostuk and Khodosovtsev 2017). First data on lichenobiota of the Teteriv River Basin appeared in the second part of 19th century (Fedorenko et al. 2006). First records of lichenicolous fungi in this area were published at the end of the 20th century (Kondratyuk et al. 1999). Before our research only one lichenicolous fungus Trichonectria hirta (A. Bloxam) Petch was known in this area. We got an interesting data on lichens and lichenicolous fungi of the territory. As a result 110 species are recorded at the first time from the Teteriv River Basin, from them 75 lichens and 36 lichenicolous fungi. The data on distribution of 37 lichenicolous fungi with the detailed localities for each of them and little important note for some of interesting and rare species are provided in this paper. 


\section{MATERIAL AND METHODS}

The Teteriv River flows in the north of Ukraine. It is a right-bank tributary of the Dniper River, the main river of Ukraine. The Teteriv River has an overall length of $365 \mathrm{~km}$, a depth of about 1.0-1.5 m and basin of 15,100 km². The Teteriv River Basin is located in the northwestern part of the Ukrainian Crystal Shield, which is largely affecting on natural conditions of the Oblast. Rivers Hnylop'yat, Huyva, Zdvyzh and Irsha are the major tributaries of the Teteriv. Outwash plains with a crystalline basement are the main type of landscape of the area. Turf-podzolic, turf-podzol, black and forest soils are the main types of soils. River banks are steep, usually to 1-2 m high and often with granite outcrops form coastal rocks. Granite outcrops also form rapids, coastal cliffs, canyons of 25-30 m tall. Most granite outcrops are located at the lower and middle course of the Teteriv River Basin (Marinich 1963).

The climate is temperate continental. Continuity of the climate increases in the direction from northwest to southeast. The average annual temperature is $6-7^{\circ} \mathrm{C}$. Average temperature of July is $19.4^{\circ} \mathrm{C}$, of January is $-5.7^{\circ} \mathrm{C}$. Average annual precipitation reaches about $562 \mathrm{~mm}$ (Marinich et al. 1985).

The small part of upper course of the Teteriv River Basin is located in the forest-steppe zone of Ukraine and the middle and lower courses are located in the forest zone of Ukraine. The predominant type of vegetation is forest vegetation accounted for more than half of the area. There are three main types of forest vegetation: 1) basiphilous beech and mixed fir-beech forests (ass. Ficario-Ulmetum campestris Knapp 1942 emend. J. Mat. 1976, Fraxino-Alnetum W. Mat. 1952, Tilio cordatae-Carpinetum betuli Tracz. 1962, Poo nemoralisTilietum cordatae Yakushenko 2004, Potentillo albae-Quercetum Libb. 1933); 2) acidophilous oak and oak-birch forests on nutrient-poor soils (ass. Carici brizoidi-Quercetum robori Orlov, Yakushenko et Vorobyov 1999); and 3) pine forests on nutrient-poor and hydromorphic soils (ass. Vaccinio uliginosi-Pinetum Kleist 1929, Molinio-Pinetum W. Mat et J. Mat. 1973, Dicrano-Pinetum Preising et Knapp ex Oberd. 1957, Peucedano-Pinetum Mat. (1962) 1973).

The distinctive feature of this area is a presence of chasmophytic vegetation of crevices, rocky ledges and faces of rocky cliffs (ass. Hypno-Polypodietum Jurko et Peciar 1963, Asplenio-Cystopteridetum fragilis Oberd. (1936) 1999, Asplenio trichomanis-bivalens-Poetum nemoralis Boscain (1970) 1971, etc.). Ombrophilous lichen communities of siliceous rock surfaces are spread on outcrops of the Crystal Shield and presented by communities of Rhizocarpetea geographici Wirth 1972. Pioneer vegetation on shallow soils on rocky siliceous outcrops on siliceous rocks (ass. Thymo pulegioidis-Sedetum sexangulare Didukh et Kontar 1998, Artemisio austriaci-Teucrietum chamaedrycis Didukh et Kontar 1998, Melico transsylvanicae-Sedetum ruprechtii Kontar 1998) are common for the whole territory (Didukh et al. 2011, Orlov and Yakushenko 2005). 
The data on lichenicolous fungi were obtained the 2013-2017 within the framework of inventory of lichenobiota of the Teteriv River Basin. Geographical coordinates of collection localities are provided by WGS-84. The material was collected using the classic methods of a field sampling. All specimens were identified in laboratory using light microscope (Kondratyuk and Martynenko 2006), special chemicals and modern literature (Calatayud et al. 2002, Diederich 1992, Hawksworth 1983, Knudsen and Kocourková 2008, Kondratyuk et al. 1999, Navarro-Rosinés et al. 1995, etc.). The nomenclature of taxa of lichenicolous fungi followed the Index Fungorum. The main collected samples of lichenicolous fungi are deposited in the Lichen herbarium of Ukraine (KW-L).

\section{Collecting localities}

1. Vinnytsia Oblast, Koziatyn Rayon, the "Sestrynivska dacha" botanical reserve,

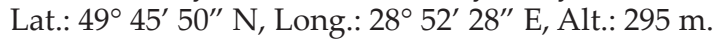

2. Zhytomyr Oblast, detailed location not known (Kondratyuk et al. 1999).

3. Zhytomyr Oblast, Korostyshiv Rayon, Korostyshiv town, right bank of the Teteriv

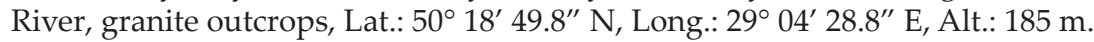

4. Zhytomyr Oblast, Korostyshiv Rayon, Korostyshiv town, right bank of the Teteriv River, granite outcrops, Lat.: $50^{\circ} 20^{\prime} 16.60^{\prime \prime} \mathrm{N}$, Long.: $29^{\circ} 04^{\prime} 29.22^{\prime \prime} \mathrm{E}$, Alt.: $181 \mathrm{~m}$.

5. Zhytomyr Oblast, Korostyshiv Rayon, left bank of the Teteriv River, granite outcrops, Lat.: $50^{\circ} 18^{\prime} 06.5^{\prime \prime}$ N, Long.: $29^{\circ} 03^{\prime} 20.5^{\prime \prime}$ E, Alt.: $184 \mathrm{~m}$.

6. Zhytomyr Oblast, Korostyshiv Rayon, mixed forest between villages Tsarivka and Kocheriv, Lat.: $50^{\circ} 21^{\prime}$ 01.4" N, Long.: 29 17' 20.4" E, Alt.: 207 m.

7. Zhytomyr Oblast, Korostyshiv Rayon, east vicinities of the Kam'ianyi Brid village, deciduous forest, Lat.: $50^{\circ} 28^{\prime} 53.5^{\prime \prime} \mathrm{N}$, Long.: $28^{\circ} 58^{\prime} 27.0^{\prime \prime}$ E, Alt.: $214 \mathrm{~m}$.

8. Zhytomyr Oblast, Korostyshiv Rayon, north part of the Korostyshiv town, Maiakovskyi street, Lat.: 50²0’24.4" N, Long.: 29 04' 13.2" E, Alt.: 198 m.

9. Zhytomyr Oblast, Korostyshiv Rayon, northeast vicinities of the Korostyshiv town, the left bank of the Teteriv River, trees along the river (near Skhidna street), Lat.: $50^{\circ} 20^{\prime}$ 25.8” N, Long.: 2904' 35.3" E, Alt.: 179 m.

10. Zhytomyr Oblast, Korostyshiv Rayon, northeast vicinities of the Horodske village, the right bank of the Teteriv River, granite outcrops, Lat.: $50^{\circ} 22^{\prime} 26.5^{\prime \prime} \mathrm{N}$, Long.: $29^{\circ}$ 10' 53.3" E, Alt.: $175 \mathrm{~m}$.

11. Zhytomyr Oblast, Korostyshiv Rayon, northeast vicinities of the Horodske village, the right bank of the Teteriv River, mixed forest, Lat.: $50^{\circ} 22^{\prime} 28.5^{\prime \prime} \mathrm{N}$, Long.: $29^{\circ} 10^{\prime}$ 26.3" E, Alt.: $179 \mathrm{~m}$.

12. Zhytomyr Oblast, Korostyshiv Rayon, northeast vicinities of the Vysokyi Kamin village, left bank of the Teteriv River, granite outcrops, Lat.: $50^{\circ} 21^{\prime} 43.1^{\prime \prime} \mathrm{N}$, Long.: $29^{\circ} 08^{\prime}$ 21.1" E, Alt.: $174 \mathrm{~m}$.

13. Zhytomyr Oblast, Korostyshiv Rayon, northern vicinities of the Korostyshiv town, mixed forest, Lat.: 50²0' 10.4" N, Long.: 29 04' 51.3” E, Alt.: 210 m.

14. Zhytomyr Oblast, Korostyshiv Rayon, vicinities of the Horodske village, left bank of the Teteriv River, granite outcrops, Lat.: $50^{\circ} 22^{\prime} 33.4^{\prime \prime}$ N, Long.: $29^{\circ} 10^{\prime} 12.8^{\prime \prime}$ E, Alt.: $173 \mathrm{~m}$.

15. Zhytomyr Oblast, Korostyshiv Rayon, southwest vicinities of the Korostyshiv town, trees along the road T0602, Lat.: 50 $18^{\prime} 33.56^{\prime \prime} \mathrm{N}$, Long.: $29^{\circ} 02^{\prime} 12.15^{\prime \prime}$ E, Alt.: $198 \mathrm{~m}$. 
16. Zhytomyr Oblast, Korostyshiv Rayon, northern vicinities of the Korostyshiv

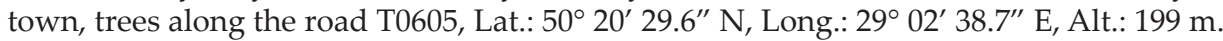

17. Zhytomyr Oblast, Korostyshiv town, the park in the town centre, Lat.: $50^{\circ} 18^{\prime}$ 57.5” N, Long.: 290 $04^{\prime} 13.0^{\prime \prime}$ E, Alt.: $186 \mathrm{~m}$.

18. Zhytomyr Oblast, Malyn town, right bank of the Irsha River, granite outcrops, Lat.: $50^{\circ} 45^{\prime} 58.9^{\prime \prime} \mathrm{N}$, Long.: $29^{\circ} 13^{\prime} 36.1^{\prime \prime}$ E, Alt.: $165 \mathrm{~m}$.

19. Zhytomyr Oblast, Romaniv Rayon, southern outskirts of the Korchivka village, trees along the road T0618, Lat.: $50^{\circ} 06^{\prime} 39.7^{\prime \prime} \mathrm{N}$, Long.: $27^{\circ} 57^{\prime} 20.3^{\prime \prime}$ E, Alt.: $280 \mathrm{~m}$.

20. Zhytomyr Oblast, east outskirts of the Korostyshiv town, the flooded granite quarry, Lat.: $50^{\circ} 18^{\prime} 56.1^{\prime \prime} \mathrm{N}$, Long.: $29^{\circ} 05^{\prime} 33.9^{\prime \prime}$ E, Alt.: $213 \mathrm{~m}$.

21. Zhytomyr Oblast, northwest vicinities of the Malyn town, "Hamarnia" locality

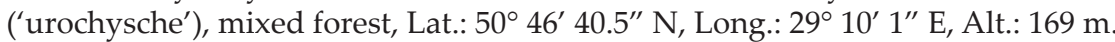

22. Zhytomyr Oblast, southwest part of the Zhytomyr city, right bank of the Kamianka River, granite outcrops, Lat.: $50^{\circ} 15^{\prime} 30.3^{\prime \prime}$ N, Long.: $28^{\circ} 38^{\prime} 36.8^{\prime \prime}$ E, Alt.: $217 \mathrm{~m}$.

23. Zhytomyr Oblast, Zhytomyr Rayon, forest between villages Tryhiria and Vysoka Pich, Lat.: $50^{\circ} 11^{\prime} 12.3^{\prime \prime} \mathrm{N}$, Long.: $28^{\circ} 20^{\prime} 25.6^{\prime \prime}$ E, Alt.: $238 \mathrm{~m}$.

24. Zhytomyr Oblast, Zhytomyr Rayon, northern vicinities of the Hodykha village, pine forest, Lat.: $50^{\circ} 11^{\prime} 49.1^{\prime \prime} \mathrm{N}$, Long.: $28^{\circ} 13^{\prime} 09.8^{\prime \prime}$ E, Alt.: $230 \mathrm{~m}$.

25. Zhytomyr Oblast, Zhytomyr Rayon, right bank of the Bobrivka River, outcrops near resort “Denyshi”, Lat.: $50^{\circ} 12^{\prime} 29.9^{\prime \prime} \mathrm{N}$, Long.: $28^{\circ} 21^{\prime}$ 53.4" E, Alt.: $238 \mathrm{~m}$.

26. Zhytomyr Oblast, Zhytomyr city, left bank of the Teteriv River, Yu. Haharin Park, outcrops near the rotunda, Lat.: 50 $14^{\prime} 39.3^{\prime \prime}$ N, Long.: $28^{\circ} 39^{\prime} 43.1^{\prime \prime}$ E, Alt.: $208 \mathrm{~m}$.

27. Zhytomyr Oblast, Zhytomyr city, left bank of the Teteriv River, near the Yu. Haharin Park, trees near the river, Lat.: 50 14'39.1" N, Long.: $28^{\circ} 39^{\prime} 48.6^{\prime \prime}$ E, Alt.: $210 \mathrm{~m}$.

\section{RESULTS AND DISCUSSION}

\section{List of species}

Species new for Ukraine are indicated by an asterisk $\left({ }^{*}\right)$.

Abrothallus caerulescens I. Kotte - 14: on thallus of Xanthoparmelia stenophylla (Ach.) Ahti et D. Hawksw. (= X. somloensis (Gyeln.) Hale) growing on rock (KW-L 70540); on thallus of Xanthoparmelia conspersa (Ehrh. ex Ach.) Hale growing on rock (KW-L 70541).

Arthonia phaeophysciae Grube et Matzer - 7: on thallus of Phaeophyscia orbicularis (Neck.) Moberg growing on Aesculus hippocastanum L., together with Lichenochora obscuroides (Linds.) Triebel et Rambold (KW-L 70536).

Athelia arachnoidea (Berk.) Jülich - 15: on thallus of Phaeophyscia sp. growing on Populus nigra L.; 17: on thallus of Phaeophyscia orbicularis growing on Aesculus hippocastanum (KW-L 70536); 19: on thallus of Physcia sp. (KW-L 70556).

${ }^{*}$ Cercidospora crozalsiana (H. Olivier) Nav.-Ros., Cl. Roux et Casares - 14: on thallus of Protoparmeliopsis muralis (Schreb.) M. Choisy growing on rock; 26: on thallus of Protoparmeliopsis muralis growing on rock (KW-L 70523). - The taxon was previously known only from France, Spain and Turkey. All the di- 
agnostic characters of our specimens agree well with the original description. Protoparmeliopsis muralis is a new host species (Navarro-Rosinés et al. 1995).

Cercidospora macrospora (Uloth) Hafellner et Nav.-Ros. - 26: on thallus of Protoparmeliopsis muralis growing on rock, together with Cercidospora crozalsiana (KW-L 70523). - The species was previously known from territories of neighbouring to the Teteriv River Basin (Fedorenko et al. 2007) and it is found in the study area for the first time. Teleomorph of this species is quite common in Ukraine. Only several records of anamorph stage of C. macrospora including those mentioned above in the cited paper are known for Ukraine.

Clypeococcum hypocenomycis D. Hawksw. - 6: on thallus of Hypocenomyce scalaris (Ach. ex Lilj.) M. Choisy growing on Pinus sylvestris L.; 22: on thallus of Hypocenomyce scalaris growing on rock; 24: on thallus of Hypocenomyce scalaris growing on Pinus sylvestris (KW-L 70531).

Cornutispora lichenicola D. Hawksw. et B. Sutton - 8: on thallus and apothecia of Massjukiella polycarpa (Hoffm.) S. Y. Kondr., Fedorenko, S. Stenroos, Kärnefelt, Elix, Hur et A. Thell growing on wooden fence (KW-L 70507). - The species is rare in the country. Our record is the second for the whole Ukraine after the Carpathian Mts and the first record for the Ukrainian Plains (Kondratyuk et al. 2003).

Erythricium aurantiacum (Lasch) D. Hawksw. et A. Henrici - 13: on thallus of Physcia stellaris (L.) Nyl. growing on Quercus robur L. (KW-L 70521); 19: on thallus of Physcia stellaris (KW-L 70520). - The species was previously known from the steppe and forest-steppe zones of Ukraine (Darmostuk and Khodosovtsev 2017). These records are the first for the forest zone of Ukraine.

Heterocephalacria physciacearum (Diederich) Millanes et Wedin - 14: on thallus of Physcia cf. stellaris growing on Pyrus communis L. (KW-L 70527). The species is rare for Ukraine. Our record is the third one for the country and the first for the forest zone of Ukraine (Darmostuk and Khodosovtsev 2017).

Intralichen christiansenii (D. Hawksw.) D. Hawksw. et M. S. Cole - 19: on apothecia of Strangospora deplanata (Almq.) Clauzade et $\mathrm{Cl}$. Roux growing on Betula pendula Roth. (KW-L 70555).

Lichenochora obscuroides (Linds.) Triebel et Rambold - 13: on thallus of Phaeophyscia orbicularis growing on Populus sp. (KW-L 70535); on thallus of Physcia sp. growing on Quercus robur (KW-L 70534); 17: on thallus of Phaeophyscia orbicularis growing on Aesculus hippocastanum (KW-L 70536, 70537).

Lichenoconium erodens M. S. Christ. et D. Hawksw. - 9: on thallus of Lecanora saligna (Schrad.) Zahlbr. growing on Betula pendula (KW-L 70560); 16: on thallus of Parmelia sulcata Taylor growing on Populus nigra (KW-L 70563, 70554); 19: on thallus of Parmelia sulcata growing on Betula pendula (KW-L 70546).

Lichenoconium lecanorae (Jaap) D. Hawksw. - 1: on apothecia of Lecanora carpinea (L.) Vain. growing on Ulmus sp. (KW-L 70544, 70545); 7: on thallus of Lecanora carpinea (L.) Vain. growing on Carpinus betulus L. (KW-L 70528); 
19: on apothecia of Lecanora conizaeoides Nyl. ex Cromb. growing on Betula pendula (KW-L 70547). - This species is quite common in Ukraine (Darmostuk and Khodosovtsev 2017), but the record from Vinnytsia Oblast provided here is the first for the forest-steppe zone of the whole country.

Lichenoconium usneae (Anzi) D. Hawksw. - 14: on thallus of Flavoparmelia caperata (L.) Hale growing on Quercus robur (KW-L 70553); 19: on thallus of Cladonia fimbriata (L.) Fr. growing on soil (KW-L 70549). - Our record is the third one for the whole territory of Ukraine after the known records from the Ukrainian Carpathians and the first record for Ukrainian Plains (Hawksworth 1992, Kondratyuk et al. 2003).

Lichenodiplis lecanorae (Vouaux) Dyko et D. Hawksw. - 9: on thallus of Lecanora saligna growing on Betula pendula (KW-L 70515); 11: on thallus of Lecanora conizaeoides growing on Betula pendula (KW-L 70529).

Lichenostigma cosmopolites Hafellner et Calat. - 3: on thallus of Xanthoparmelia conspersa growing on rock; on thallus Xanthoparmelia stenophylla growing on rock; 10: on thallus of Xanthoparmelia stenophylla growing on rock (KW-L 70542); 12: on thallus of Xanthoparmelia cf. stenophylla growing on rock (KW-L 70565).

*Lichenostigma epipolina Nav.-Ros., Calat. et Hafellner - 4: on thallus of Buellia badia (Fr.) A. Massal. growing on rock; 10: on thallus of Acarospora fuscata growing on rock, together with Muellerella pygmaea (KW-L 70533, 70552). - This taxon was previously known from Europe, Asia and Northern Africa. Buellia badia and Acarospora fuscata are new hosts for this lichenicolous fungus (Calatayud et al. 2002).

Lichenothelia convexa Henssen - 14: on rock; 25: on rock; 26: on rock. - This species was previously known from forest-steppe, steppe, Ukrainian Carpathians and Crimean Mts of Ukraine (Darmostuk and Khodosovtsev 2017). These records are the first for the forest zone of Ukraine.

Lichenothelia scopularia (Nyl.) D. Hawksw. - 14: on rock.

*Lichenothelia tenuissima Henssen - 3: on rock (KW-L 70512); 10: on rock (KW-L 70561); 20: on rock (KW-L 70511). - The species was previously known from Europe and North America. It can grow on acid rocks and on some crustose lichens (Henssen 1987).

Marchandiomyces corallinus (Roberge) Diederich et D. Hawksw. - 14: on thallus of Acarospora sp. (KW-L 70564). - Until recently this species was known in Ukraine only from the steppe zone and from the Ukrainian Carpathians. Our record is the first for the forest zone of the country (Khodosovtsev and Khodosovtseva 2014, Kapets 2017).

Monodictys epilepraria Kukwa et Diederich - 3: on thallus of Lepraria sp. growing on rock (KW-L 70513); 14: on thallus of Lepraria neglecta (Nyl.) Erichsen growing on rock (KW-L 70537, 70538); 25: on thallus of Lepraria membranacea (Dicks.) Vain. growing on rock (KW-L 70522). - Only one distribution 
record of this species was hitherto known for Ukraine from the Carpathian Mts (Vondrák et al. 2010). Our data are the first for the Ukrainian Plains.

Muellerella pygmaea (Körb.) D. Hawksw. - 10: on thallus of Acarospora fuscata (Nyl.) Th. Fr. growing on rock, together with Lichenostigma epipolina (KW-L 70533); 18: on thallus Lecidea fuscoatra (L.) Ach. growing on rock (KW-L 70527).

Muellerella erratica (A. Massal.) Hafellner et V. John - 26: on thallus of Bellemerea cupreoatra (Nyl.) Clauzade et $\mathrm{Cl}$. Roux growing on rock (KW-L 70558). This record is the second for the whole Ukraine after the published record from the Crimean Mts and the first record for the Ukrainian Plains (Vondrák 2006).

*Polysporina subfuscescens (Nyl.) K. Knudsen et Kocourk. - 3: on thallus of Acarospora sp. growing on rock (KW-L 70492); 4: on thallus of Acarospora sp. growing on rock (KW-L 70494); 10: on thallus of Acarospora fuscata (Nyl.) Th. Fr. growing on rock (KW-L 70532); 12: on thallus of Acarospora fuscata growing on rock; 18: on thallus of Acarospora sp. - The combination was proposed by K. Knudsen and J. Kocourková with clarification of misapplied name Polysporina lapponica to this species (Knudsen and Kocourková 2008). Perhaps the records of lichenicolous Polysporina lapponica from the steppe zone of Ukraine over time will be redefined as Polysporina subfuscescens, but now there is no information about this (Khodosovtsev and Zavyalova 2008). All the diagnostic characteristics of our specimens agree well with the original description of Polysporina subfuscescens. Therefore, we have all grounds to consider our records from the study area as the first record for Ukraine (Kapets et al. 2015).

Pronectria leptaleae (J. Steiner) Lowen - 1: on thalli and apothecia of Physcia stellaris growing on Quercus robur (KW-L 70551, 70557). - The species was hitherto known in Ukraine only from the forest and steppe zones. This is the first record for the forest-steppe zone of Ukraine (Darmostuk and Khodosovtsev 2017).

Pyrenochaeta xanthoriae Diederich - 1: on thallus of Xanthoria parietina growing on Ulmus sp. (KW-L 70548). - This species was hitherto known in Ukraine only from the steppe zone (Darmostuk and Khodosovtsev 2017). This is the first record for the forest-steppe zone of the country.

Sclerococcum sphaerale (Ach.) Fr.-3: on thallus of Lecanora sp. (KW-L 70514). - The species was known in Ukraine until now only from the steppe zone. This is the first record for the forest zone of the country (Kondratyuk et al. 1999).

Sphaerellothecium propinquellum (Nyl.) Cl. Roux et Triebel - 1: on thallus of Lecanora carpinea (L.) Vain. growing on Ulmus sp. (KW-L 70524). - This is the second record for the whole Ukraine after the Crimean Mts and the first record for the Ukrainian Plains (Khodosovtsev 2013).

Stigmidium fuscatae (Arnold) R. Sant. - 10: on thallus Acarospora fuscata growing on rock, with Thelocarpon epibolum Nyl. (KW-L 70496, 70495).

Stigmidium squamariae (B. de Lesd.) Cl. Roux et Triebel -18: on thallus of Protoparmeliopsis muralis growing on rock (KW-L 70562). 


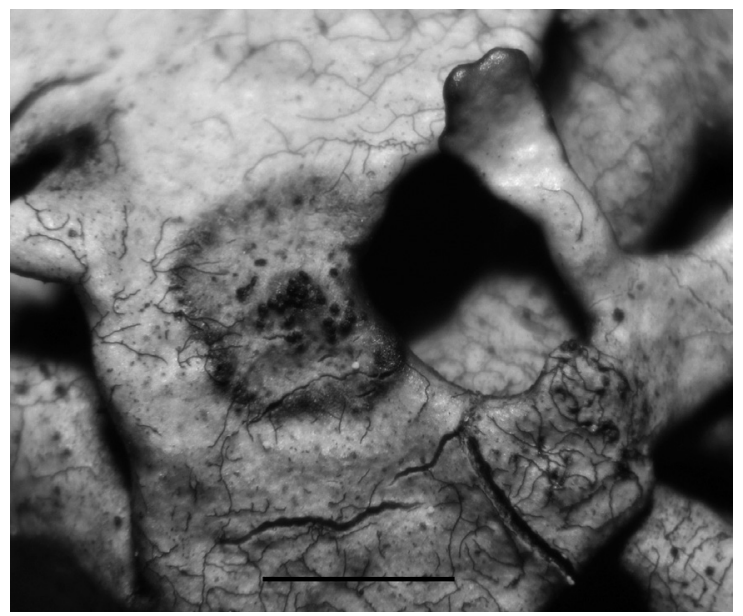

Fig. 1. Stigmidium xanthoparmeliarum on thallus of Xanthoparmelia conspersa. Scale $5 \mathrm{~mm}$ (photo of N. Kapets)

Stigmidium xanthoparmeliarum Hafellner - 3: on thallus of Xanthoparmelia conspersa (KW-L 70519); 10: on thallus of Xanthoparmelia stenophylla (KW-L 70539) (Figs 1-2). - This species until recently was known in Ukraine only from the steppe zone (Darmostuk and Khodosovtsev 2017). Our records are the first ones for the forest zone of Ukraine.

*Taeniolella beschiana Diederich - 6: on thallus of Cladonia ramulosa (With.) J. R. Laundon growing on soil (KW-L 70526). - This lichenicolous fungus is known from Europe and Asia (Diederich 1992).

Taeniolella phaeophysciae D. Hawksw. - 13: on thallus Phaeophyscia ciliata (Hoffm.) Moberg growing on Populus tremula L. (KW-L 70525).

Taeniolella punctata M. S. Christ. et D. Hawksw. - 23: on thallus of Graphis scripta (L.) Ach. growing on Fagus sylvatica L. (KW-L 70530, 70559).

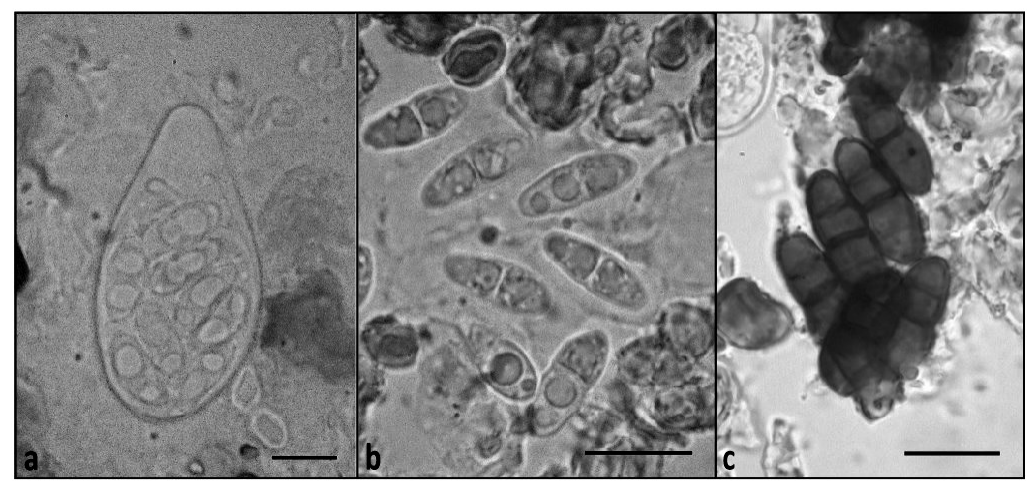

Fig. 2. Stigmidium xanthoparmeliarum. $a=$ ascus with ascospores, $b=$ immature hyaline ascospores; $c=$ mature brown $2-3$ septate ascospores. Scale: $10 \mu \mathrm{m}$ (photo of N. Kapets) 
Trichonectria hirta (A. Bloxam) Petch - 2: on thallus of Scoliciosporum chlorococcum (Graewe ex Stenh.) Vězda (Fedorenko et al. 2006, Kondratyuk et al.1999).

Xanthoriicola physciae (Kalchbr.) D. Hawksw. - 1: on thalli and apothecia of Xanthoria parietina (L.) Th. Fr. growing on Quercus robur; 11: on thallus of Xanthoria parietina growing on Robinia pseudo-acacia L.; 16: on thalli and apothecia of Xanthoria parietina growing on Populus nigra; 19: on thallus of Xanthoria parietina growing on Betula pendula; 21: on thalli and apothecia of Xanthoria parietina growing on Populus tremula; 27: on thalli and apothecia of Xanthoria parietina growing on Populus tremula.

Five species, Cercidospora crozalsiana, Lichenostigma epipolina, Lichenothelia tenuissima, Polysporina subfuscescens and Taeniolella beschiana, are for the first time recorded for Ukraine. Some of the found species are rare for Ukraine and previously were known only from the mountainous part of the country. Our records of Cornutispora lichenicola, Lichenoconium usneae, Monodictys epilepraria, Muellerella erratica, Sphaerellothecium propinquellum are the first records for the Ukrainian Plains. New habitats of some species for Ukraine are hereby reported, too. Lichenicolous fungi Erythricium aurantiacum, Heterocephalacria physciacearum, Lichenothelia convexa, Marchandiomyces corallinus and Stigmidium xanthoparmeliarum are reported for the first time from the forest zone as well as Lichenoconium lecanorae, Pronectria leptaleae and Pyrenochaeta xanthoriae are reported for the first time from the forest-steppe zone of Ukraine.

Acknowledgements - We thank to the administration of state-owned enterprise "Khmilnytskyi lishosp" for supporting our research of lichenobiota of "Sestrynivska dacha" botanical reserve. Special thanks to our colleague Dr Mariia Zykova, Haluna Redko and Tetiana Suprun for the help during field research.

\section{REFERENCES}

Calatayud, V., Navarro-Rosinés, P. and Hafellner, J. (2002): A synopsis of Lichenostigma subgen. Lichenogramma (Arthoniales), with a key to the species. - Mycol. Research. 106(10): 1230-1242. https://doi.org/10.1017/s095375620200655x

Darmostuk, V. V. and Khodosovtsev, A. Ye. (2017): Lichenicolous fungi of Ukraine: an annotated checklist. - Studies in Fungi 2(1): 138-156. https://doi.org/10.5943/sif/2/1/16

Didukh, Y. P., Fitsailo, T. V., Korotchenko, I. A., Iakushenko, D. M. and Pashkevych, N. A. (2011): Biotopes of forests and forest-steppe zones of Ukraine. - Ltd. "Makros", Kyiv, 288 pp. [in Ukrainian]

Diederich, P. (1992): New or interesting lichenicolous fungi 2. Taeniolella beschiana new species and Taeniolella serusiauxi new species (Hyphomycetes). - Bull. Soc. Nat. Luxembourg. 93: 155-162.

Fedorenko, N. M., Kondratyuk, S. Ya. and Orlov, O. O. (2006): Lichen-forming and lichenicolous fungi of Zhytomyr Oblast. - Ruta, Volyn, Zhytomyr, 148 pp. [in Ukrainian] 
Fedorenko, N. M., Nadeina, O. V. and Kondratyuk, S. Ya. (2007): New and rare lichenicolous fungi from Ukraine. - Ukr. Bot. J. 64(1): 47-56. [in Ukrainian]

Hawksworth, D. L. (1983): A key to the lichen-forming, parasitic, parasymbiotic and saprophytic fungi occurring on lichens in the British Isles. - Lichenologist 15(1): 1-44. https://doi.org/10.1016/s0007-1536(84)80239-9

Hawksworth, D. L. (1992): Nine lichenicolous fungi from Transcarpathians new for Ukraine. - Ukr. Bot. J. 49(3): 99-101.

Henssen, A. (1987): Lichenothelia, a genus of microfungi on rocks. - Bibl. Lichenol. 25: 257-293.

Kapets, N. V. (2016): New and rare to Ukraine lichenicolous fungi. - Ukr. Bot. J. 73(1): 90-92. [in Ukrainian] https://doi.org/10.15407/ukrbotj73.01.090

Kapets, N. V. (2017): New and rare species of lichen-forming and lichenicolous fungi for Ukraine from Carpathian Mountains. - Studia UBB Biol., Sp. Iss. 62: 134-135.

Kapets, N. V., Pleskach, L. Yu., Popova, L. P., Fedorenko, N. M., Litovynska, A. V., Shershova, N. V. and Kondratyuk, S. Ya. (2015): New to Ukraine and rare species of lichenforming and lichenicolous fungi. - Ukr. Bot. J. 72(2): 156-163. [in Ukrainian] https:// doi.org/10.15407/ukrbotj72.02.156

Khodosovtsev, A. Ye. (2013): Lichen-forming and lichenicolous fungi from Aju-Dag Mt. new to Ukraine and Crimea. - Chornomors'k. bot. z. 9(1): 84-88. [in Ukrainian] https:// doi.org/10.14255/2308-9628/13.91/7

Khodosovtsev, A. Ye. and Khodosovtseva, Yu. A. (2014): Lichens and lichenicolous fungi of the arboretum F. E. Falz-Fein Biosphere reserve of 'Askania-Nova'. - Chornomors'k. bot. z. 10(4): 515-526 https://doi.org/10.14255/2308-9628/14.104/6

Khodosovtsev, A. Ye. and Zavyalova, T. V. (2008): The lichenological zoning of the rocks outcrops of the Kayinkulak River shores (Zaporozhskaya oblast, Chernigovsky Rayon). - Visnyk of Odessa Nat. Univ., Biol. 13(16): 56-60. [in Ukrainian]

Knudsen, K. and Kocourková, J. (2008): A study of lichenicolous species of Polysporina (Acarosporaceae). - Mycotaxon. 105: 149-164.

Kondratyuk, S. Ya. and Martynenko, V. G. (2006): Lichen indication (manual). - TOV 'KOD', Kiev-Kirovograd. 260 pp. [in Ukrainian]

Kondratyuk, S. Ya., Andrianova, T. V. and Tykhonenko, Yu. Yu. (1999): Study of mycobiota diversity of Ukraine (lichenicolous, Septoria and Puccinia fungi). - M. G. Kholodny Institute of Botany, Phytosociocentre, Kyiv, 122 pp. [in Ukrainian]

Kondratyuk, S. Ya., Popova, L. P., Lackovicova, A. and Pišút, I. (2003): A catalogue of the Eastern Carpathian Lichens. - M. H. Kholodny Institute of Botany, Kyiv, Bratislava, 264 pp.

Marinich, A. M. (1963): The geomorphology of South Polessye. - Publishing House of Kyiv State University, Kiev, 252 pp. [in Russian]

Marinich, A. M., Pashchenko, V. M. and Shyshchenko, P. H. (1985): The nature of the Ukrainian SSR. Landscapes and physical-geographical oblastalization. - Naukova Dumka, Kiev, 224 pp. [in Russian]

Navarro-Rosinés, P., Roux, C. and Casares, M. (1995): Hongos liquenícolas de Squamarina II: Sobre la identidad de "Didymella" crozalsiana (Ascomycetes). - Cryptogamie Bryol. Lichénol. 16(2): 99-103.

Orlov, O. O. and Yakushenko, D. M. (2005): Plant cover of projected Korostyshiv Nature National Park. - Fitosotsiotsentr, Kyiv, 180 pp. [in Ukrainian]

Vondrák, J. (2006): Lichen-forming and lichenicolous fungi in the herbarium Jan Vondrak (PRA). - URL http://botanika.prf.jcu.cz/lichenology/

Vondrák, J., Palice, Z., Khodosovtsev, A. and Postoyalkin, S. (2010): Additions to the diversity of rare or overlooked lichens and lichenicolous fungi in Ukrainian Carpathians. - Chornomors'k. bot. z. 6(1): 6-34. https://doi.org/10.14255/2308-9628/10.61/1 